\title{
A Scientific Approach Based on Portfolio Assessment for Autonom Problem Solving
}

\author{
Triesninda Pahlevi ${ }^{1}$, Brillian Rosy ${ }^{2}$, Meylia Elizabeth Ranu ${ }^{3}$
}

\begin{tabular}{l} 
ARTICLE INFO \\
\hline Article History: \\
Received 28.01.2018 \\
Received in revised form \\
14.03.2018 \\
Accepted \\
Available online 01.04 .2018
\end{tabular}

\begin{abstract}
The aim of the current study is: 1) application of a scientific approach based on portfolio assessment in the English correspondence course; (2) learning outcome in English correspondence course; (3) constraints in applying a scientific approach based on portfolio assessment. The participants include 83 students of Education Studies Program Administration Office at the State University of Surabaya. this research uses a qualitative approach and this type of research is classroom action research. The results showed that the application of Scientific approach -based portfolio assessment to improve learning outcomes by $41 \%$ is the difference between pre-test and post-test. The percentage of students who complete the study is $90 \%$. Students are difficult to arrange the portfolio and the preparation takes a long time. While the advantage is to increase students' independence to solve problems and they can plan their long-term goals.
\end{abstract}

(C) 2018 IJERE. All rights reserved

Keywords:

Scientific approach, Portfolio Assesment, Learning Outcomes.

$\begin{array}{ll} & \text { Keywords: } \\ \text { Scientific approach, Portfolio Assesment, Learning Outcomes. }\end{array}$

\section{INTRODUCTION}

The purpose of national education requires that a teacher should have a wide range of professional competencies and skills. A teacher must have skills in managing his class (ŞİMŞEK, 2017). In addition, the skills a teacher must possess are skills for evaluating and assessing his or her students. The main requirement of being a teacher is mastering skills and curriculum (Duman \& Karagöz, 2016). Surapranata \& Hatta (2004) stated that "In education, the following three things must be mastered by an educator, the curriculum, the learning process, and the scoring system. All three must be controlled equally". If one of the three components is weak, then it can not be said as a professional educator because it will fail to achieve the expected output and outcome. An educator who mastered the curriculum and learning process but lacked understanding in the assessment, it would be fatal for the learners (Olds, Moskal, \& Miller, 2005). This is because educators judge or impose an inappropriate verdict on their students (Van den Bergh et al., 2006).

The scientific approach is a learning process by performing the steps of observation, formulating problems, proposing or formulating hypotheses, collecting data, analyzing data to draw conclusions (Budiyanto, Waluyo, \& Mokhtar, 2016; Machin, 2014; Marjan, Arnyana, \& Setiawan, 2014; Van Joolingen, De Jong, Lazonder, Savelsbergh, \& Manlove, 2005). In the learning activities, this learning uses student-centered inquiry and inquiry learning, while the direct learning activities are teacher-centered (Majid, 2011). The results of Janbuala, Dhirapongse, Issaramanorose, \& Iembua (2013) study show that scientific approach can improve children's science skills. The document generated in the form of student duties collected and used appropriate assessment to assess student work.

Assessment cannot be released with the role of educator. Assessment is one of the key indicators to determine the success or failure of educators as learning agents and learners prior to selecting appropriate targeting methods that are considered appropriate to existing learning conditions so that for the next step of effectiveness, efficiency and power the pull of learning can be well organized and can produce a competent learning outcomes that can make the assessment of learning is positive, according to national education goals. This is supported by Havnes \& McDowell (2007), "When teachers assess work and student progress, teachers can also see how successful teaching is." Assessment in learning does not always use the assessment of test forms to measure student achievement. Popham (2011) collects information about students by formal assessment and informal assessment to provide more accurate information about students' skills and attitudes.

${ }^{1}$ Corresponding e-mail: triesnindapahlevi@unesa.ac.id,orcid.org/0000-0003-1717-9409 Universitas Negeri Surabaya ${ }^{1}$, orcid.org/0000-0001-6729-9674 Universitas Negeri Surabaya ${ }^{2}$, orcid.org/0000-0002-2309-1414, Universitas Negeri Surabaya ${ }^{3}$ 
The Concept of Class-Based Assessment is one form of assessment that can provide information to teachers about student learning outcomes based on the stages of learning progress so that the portrait or profile capabilities of students in accordance with the competencies established in the curriculum. ClassBased is an integral part of the learning process which is carried out as a process of collecting and utilizing comprehensive information about learning outcomes obtained by students to determine the level of achievement and mastery of competencies as determined in the curriculum and as a feedback improvement of the learning process (Sanjaya, 2008). It is conducted to provide balance to the three cognitive, affective, and psychomotor domains by using various forms and models of assessment formally and unofficially with sustainable. It is done by collecting student work evidence (portfolio), work (product), assignment (project), performance (performance), and written test (paper and pencil test).

According to Majid (2011) collection of students' work that provides an information for an assessment referred to as a portfolio. Portfolio is defined as a collection of student tasks with a particular purpose and integrated which is selected according to the guidelines specified (Fajar, 2005). The work of students in the portfolio is usually a very important and important work to be displayed. Portfolios are very diverse, therefore teachers as educators can collect them in many ways according to the purpose, the way they will be used, the level of the learner or the type of activities performed.

The student work collections are well documented and organized so as to represent an organized learning history and demonstration of achievement of things (Baeten, Dochy, \& Struyven, 2008). Through the work of selected students, the teacher can understand the students' views of themselves as learners. So, in this case, the teacher acts as a facilitator and students are given the freedom to choose their own learning resources in accordance with the foundation for the constructivism that occurs in the real world.

The results of the previous research indicate that the assessment portfolio showed positive results to improve student learning outcomes (Tiwari \& Tang, 2003). The assessment portfolio was developed to provide a learning achievement assessment of learners drawn from formative and summative values (Dannefer \& Henson, 2007). From the results of this study can be concluded that the portfolio assessment is very effective to be applied as a tool of assessment of learning outcomes.

In contrast to the results of the above research, the results of research by Struyven, Dochy, Janssens, Schelfhou, \& Gielen (2006) suggests that the assessment portfolio does not deepen learners' approaches to learning, nor are other innovative assessment models in their research (case-based assessment and peer assessment). Learners who have high learning activities tend to experience high pressure and workload, resulting from very complex tasks, and lack of inter-group collaboration. Learners who have a high initial preference for learning get a lower assessment portfolio score (Baeten et al., 2008).

English Correspondence Course is an important subject and must be mastered by students of Administrative Education Office because, in the world of office, correspondence is an activity that is always associated with communication and correspondence plays an important role to disseminate the activities of a company, both to internal and external parties company. Therefore, students are required to be skilled in preparing the letter in accordance with the rules of the correct writing order so that the need for repetitive exercise. In order for student tasks are not scattered then it takes an appropriate assessment of portfolio assessment.

The reasons for using portfolio assessment in this research are (1) a scientific approach based on portfolio assessment has not been applied in this campus; (2) a desire to increase liveliness, hard work, and student independence as an effort to improve student learning outcomes.

Based on the above background, aim of the research are: (1) application of a scientific approach based on portfolio assessment in the English correspondence course; (2) learning outcome in English correspondence course; (3) constraints in applying a scientific approach based on portfolio assessment.

\section{METHOD}

This research was conducted by using a qualitative approach. This type of research is classroom action research. Action research involves teachers in research with the aim of improving an existing problem in the 
classroom (Cain, 2011). The subjects of this study are students of Education Studies Program Administration 2015 academic year, amounting to 83 students who are taking English Correspondence courses. Stages of this class action research start from planning, implementation, observation, and reflection.

\section{Material}

Data collection techniques conducted in this study through observation, interviews, documentary studies, field notes, and student learning tests. Observations were made by peers, while field notes were used to supplement unrecorded data in the observation sheets. The test in this study was conducted to find out how much students' understanding of the material presented after the portfolio assessment was applied. The test is done at the beginning before taking action and ending after the action.

\section{Data Analyses}

Qualitative analysis techniques refer to the model of analysis of Hubermen \& Miles (2002) conducted in 3 consecutive components, namely: (1) data reduction, (2) Presentation of data, (3) Conclusion. Data reduction includes the selection of data through summary or brief descriptions, and data classification into a broader pattern. Presentation of data is done in order to organize data which is compilation of information systematically from result of reduction. The conclusion is an effort to search the meaning of data, record regularity, and data classification.

\section{FINDINGS}

The implementation stage of action I require five meetings. Before performing the initial action, students do a pre-test to find out the student's initial ability. The results of pre-test can be seen in Table 1 .

Table 1. Pre Test Results and Post Test Cycle I

\begin{tabular}{cccccc}
\hline & \multicolumn{2}{c}{ Pre Test } & \multicolumn{3}{c}{ Post Test } \\
Scor & $\begin{array}{c}\text { Value } \\
\text { Criteria }\end{array}$ & $\begin{array}{c}\text { Number of } \\
\text { Students }\end{array}$ & $\begin{array}{c}\text { Persentage } \\
(\%)\end{array}$ & $\begin{array}{c}\text { Number of } \\
\text { Students }\end{array}$ & $\begin{array}{c}\text { Persentage } \\
\text { (\%) }\end{array}$ \\
\hline$>=85$ & $\mathrm{~A}$ & 5 & 6 & 10 & 12 \\
$>=80$ & $\mathrm{~A}-$ & 8 & 10 & 8 & 10 \\
$>=75$ & $\mathrm{~B}+$ & 10 & 12 & 15 & 18 \\
$>=70$ & $\mathrm{~B}$ & 10 & 12 & 15 & 18 \\
$>=65$ & $\mathrm{~B}-$ & 16 & 19 & 25 & 30 \\
$>=60$ & $\mathrm{C}+$ & 20 & 24 & 10 & 12 \\
$>=55$ & $\mathrm{C}$ & 10 & 12 & - & - \\
$>=40$ & $\mathrm{D}$ & 4 & 5 & - & - \\
$>40$ & $\mathrm{E}$ & - & - & - & - \\
\hline
\end{tabular}

From table 1 the highest value obtained from the pre-test is 90 and the lowest value is 40 , while the average value of pre-test in cycle I am 67.5. Students who complete the study reached $28 \%$. Students are said to be thoroughly studied in English Correspondence courses if they reach a grade above or equal to 75 or reach a presentation of $75 \%$.

In the implementation of the cycle I or II learning steps adapted to the approach of scientific approach are: (1) observe; (2) questioning; (3) collecting data; (4) associate, (5) communicate. The results of these documents are then kept by the students as the completeness of their portfolio assessment.

After the fifth meeting, there is a post-test to see the student's final ability after applying the portfolio assessment. Table 1 in the post-test column shows that the completed student reaches $48 \%$ with score $>=75$. The highest post-test score is 94 and the lowest score is 61 . While the average post-test score is 73 . There is an increasing number of the complete student before and after giving of action cycle I that is equal to $20 \%$. Based on the data then the student has not reached the completeness of study because the percentage of overall learning outcomes less than $70 \%$. 
In addition to the teacher's portfolio assessment, students are required to conduct portfolio assessments of themselves and the work of others. Portfolio assessment by students themselves and by friends of students is expected to make an assessment of the results of his own work and the work of others. Thus, students will be able to assess the extent to which success in learning or development in the achievement of competence so that students can find a solution to any weaknesses or shortcomings that still have.

Based on observations and field notes, it can be seen that reflection in cycle I found that (1) there are still many students who have not understood in preparing their portfolio because this assessment has never been used before; (2) it is necessary to add exercise questions to compose a sentence in an English letter; (3) make the project task for them very heavy to be portfolio. The results of the cycle I reflection can be used as a plan and improvement for the implementation of action cycle II.

In the second cycle of action, it takes five meetings to carry out the action. Similar to cycle I, the implementation of action cycle II begins with a pre-test. The results of pre-test cycle II can be seen in table 2 .

Table 2. Pre Test Results and Post Test Cycle II

\begin{tabular}{|c|c|c|c|c|c|}
\hline \multirow{2}{*}{ Scor } & \multirow{2}{*}{$\begin{array}{l}\text { Value } \\
\text { Criteria }\end{array}$} & \multicolumn{2}{|c|}{ Pre Test } & \multicolumn{2}{|c|}{ Post Test } \\
\hline & & $\begin{array}{c}\text { Number of } \\
\text { Students }\end{array}$ & $\begin{array}{c}\text { Persentage } \\
\text { (\%) }\end{array}$ & $\begin{array}{c}\text { Number of } \\
\text { Students }\end{array}$ & $\begin{array}{c}\text { Persentage } \\
\text { (\%) }\end{array}$ \\
\hline$>=85$ & $A$ & 10 & 12 & 19 & 23 \\
\hline$>=80$ & $A-$ & 8 & 10 & 23 & 28 \\
\hline$>=75$ & $B+$ & 23 & 28 & 20 & 24 \\
\hline$>=70$ & $B$ & 15 & 18 & 21 & 25 \\
\hline$>=65$ & B- & 20 & 24 & - & - \\
\hline$>=60$ & $\mathrm{C}+$ & 7 & 8 & - & - \\
\hline$>=55$ & $C$ & - & - & - & - \\
\hline$>=40$ & $\mathrm{D}$ & - & - & - & - \\
\hline$<40$ & $E$ & - & - & - & - \\
\hline
\end{tabular}

The result of pre-test cycle II shows that the percentage of learning mastery is $49 \%$ that is 41 students. The highest score obtained in cycle II is 93 and the lowest score is 64. While the average pre-test value of cycle II is 74. From the presentation of learning completeness, the students' initial ability in cycle II is still below the percentage of completeness $(49 \%<75 \%)$.

In this cycle, lecturers give more direction in preparing their portfolios, so they are not confused to compile the portfolio. Students are invited to creatively arrange their portfolio so that the arrangement of the portfolio does not seem monotonous. Not only that, lecturers are more motivating students so they do not feel bored composing the portfolio.

After doing cycle II in accordance with the cycle of a project-based learning based on portfolio assessment then conducted a post-test to measure student learning outcomes. The result of post-test on the second cycle action in table 2 shows that the presentation of learning completeness in post-test cycle II is $90 \%$, which means that the students are declared thoroughly studied. The average learning outcomes in cycle II is 80 , while the highest score is 94 and the lowest score is 74 . There is an increasing number of students who complete the study before and after giving action on the first cycle that is equal to $41 \%$.

At the end of the meeting, the students fill out a questionnaire to find out the students' opinions about the scientific approach based on the portfolio assessment using the Guttman scale. Student questionnaires can be seen in table 3 . 
Table 3. Questionnaire Scientific Approach Approach-Based Portfolio Assessment

\begin{tabular}{|c|c|c|c|c|c|}
\hline \multirow{2}{*}{ No } & \multirow{2}{*}{ Statement } & \multicolumn{2}{|c|}{ Number of Students } & \multicolumn{2}{|c|}{ Percentage (\%) } \\
\hline & & Yes & No & Yes & No \\
\hline 1 & $\begin{array}{l}\text { A scientific approach } \\
\text { based on portfolio } \\
\text { assessment can show } \\
\text { progress in learning. }\end{array}$ & 55 & 28 & 66 & 34 \\
\hline 2 & $\begin{array}{l}\text { Scientific approach based } \\
\text { approach portfolio } \\
\text { assessment can show the } \\
\text { best work }\end{array}$ & 60 & 23 & 72 & 28 \\
\hline 3 & $\begin{array}{l}\text { Scientific approach based } \\
\text { on the portfolio } \\
\text { assessment can show the } \\
\text { complete learning process } \\
\text { and results }\end{array}$ & 80 & 3 & 96 & 4 \\
\hline 4 & $\begin{array}{l}\text { Scientific approach based } \\
\text { approach portfolio } \\
\text { assessment can show the } \\
\text { ability to cooperate with } \\
\text { others }\end{array}$ & 35 & 48 & 42 & 58 \\
\hline 5 & $\begin{array}{l}\text { Scientific approach can } \\
\text { show the ability to solve } \\
\text { problems }\end{array}$ & 68 & 15 & 82 & 18 \\
\hline 6 & $\begin{array}{l}\text { Scientific approach based } \\
\text { portfolio assessment } \\
\text { approach can provide an } \\
\text { assessment of the work } \\
\text { itself }\end{array}$ & 71 & 12 & 86 & 14 \\
\hline 7 & $\begin{array}{l}\text { Portfolio assessment can } \\
\text { set long-term goals for } \\
\text { yourself }\end{array}$ & 61 & 22 & 74 & 26 \\
\hline 8 & $\begin{array}{l}\text { Portfolio preparation is } \\
\text { difficult }\end{array}$ & 63 & 20 & 76 & 24 \\
\hline 9 & $\begin{array}{l}\text { Portfolio preparation takes } \\
\text { a long time }\end{array}$ & 65 & 18 & 78 & 22 \\
\hline
\end{tabular}

From the results of the questionnaire in table 3 above shows that $66 \%$ of students think that the approach of scientific approach portfolio assessment can show the development in learning, $72 \%$ of students think that the approach of portfolio assessment based scientific approach can show the best work, $96 \%$ of students think the portfolio-based approach to scientific approach Assesment can show complete process and learning outcomes, $58 \%$ of students believe that the approach of portfolio assessment based scientific approach can not demonstrate the ability to cooperate with others, $82 \%$ of students believe that the approach of portfolio assessment based scientific approach can show the ability to solve problems, $86 \%$ portfolio assessment based scientific approach can provide an assessment of the work itself, $76 \%$ of students think the 
assessment portfolio can set long-term goals for themselves, $76 \%$ students found that assessment of the assessment portfolio was difficult, and $78 \%$ of students thought that portfolio preparation took a long time.

\section{RESULTS, DISCUSSION, AND SUGGESTIONS}

The results showed that the approach of a scientific approach based on portfolio assessment can improve student learning outcomes that experienced an increase of $41 \%$. This study was conducted for two cycles. The first cycle is evaluated because $48 \%$ of students are still not complete learning. From the results of learning, reflection found that in the first cycle of teachers have done the learning process with a scientific approach, and there are still many students who do not understand the preparation of the portfolio. The first cycle reflection is used as the basis for preparing the next cycle II planning. In action studies, teachers should do reflection because teachers have a considerable influence in the classroom (Cain, 2011). Reflection serves as a direction for teachers for their development (Mansvelder-Longayroux, Beijaard, \& Verloop, 2007). Students who achieve learning obstacles in cycle II reached $90 \%$ which means that the application of scientific approach based portfolio assessment improves student learning outcomes. The scientific approach significantly influences the learning outcomes (Machin, 2014; Marjan et al., 2014; Mulyono, Bintari, Rahayu, \& Widiyaningrum, 2012). While the portfolio assessment provides changes to the learning process for the better (Duman \& Karagöz, 2016) and the assessment portfolio shows positive results to improve student learning outcomes (Dannefer \& Henson, 2007; Tiwari \& Tang, 2003; Üstünel \& Deren, 2010). In contrast to the results of research by (Struyven et al., 2006) show that the assessment portfolio does not deepen the learner's approach to learning.

The results showed that the approach of scientific approach portfolio assessment has advantages and weaknesses. The disadvantage is the preparation of a difficult portfolio and takes a relatively similar time. While the advantages are: (1) can show the development in learning; (2) can show the process and complete learning outcomes; (3) scientific approach based on portfolio assessment can improve learning outcomes; (4) can enhance cooperation with others; (5) can improve and develop student insight in solving problems; (6) can educate students to reflect on their learning experience; (7) may conduct self-assessment and assess the work of others so that the student becomes aware of the learning progress and long-term goals; (8) Improve communication and relationships between students and between students and lecturers. Students together with teachers can formulate their future through the portfolio assessment, the assessment portfolio fosters student self-reliance and they know the learning progress (Dannefer \& Henson, 2007; MansvelderLongayroux et al., 2007). A scientific approach invites students to solve problems through three main steps of observation, generalization, and hypothesis (Griffith, 2007). The scientific-based learning approach is more effective than traditional learning (Budiyanto et al., 2016).

The success of learning is not only influenced by the methods and assessment used by teachers. So the teacher should pay attention to the factors of success of learning. The success of learning is influenced by (1) students; (2) teachers; (3) educational objectives; (4) learning materials; (5) learning environment (Budiyanto et al., 2016). The most important factor is teachers because this is the determinant of student success in learning (Sani, 2013). Teachers should be innovate to find appropriate strategies, methods, models and pressures in learning such as using a scientific approach to the learning process. This is able to improve students' ability to solve problems (Reif, 1981; Wieman, 2007). The results of this study indicate that scientific approach is able to improve students' ability to solve problems.

\section{REFERENCES}

Baeten, M., Dochy, F., \& Struyven, K. (2008). Students' approaches to learning and assessment preferences in a portfolio-based learning environment. Instructional Science, 36(5-6 EFFECTS OF CONSTR), 359-374. https://doi.org/10.1007/s11251-008-9060-y

Budiyanto, M. A. K., Waluyo, L., \& Mokhtar, A. (2016). Implementasi pendekatan saintifik dalam pembelajaran di pendidikan dasar di malang. Proceeding Biology Education Conference, 13(1), 46-51.

Cain, T. (2011). Teachers' classroom-based action research. International Journal of Research $\mathcal{E}$ Method in Education, 34(1), 3-16. 
Pahlevi,T., Rosy,B. \& Ranu,E.M. (2018). A scientific approach based on portfolio assessment for autonom problem solving. International Journal of Educational Research Review,3 (2), 29-36.

Dannefer, E., \& Henson, L. (2007). The portfolio approach to competency-based asessment at the Cleveland Clinic Lerner College of Medicine. Academic Medicine, 82(5), 439-502.

Duman, T., \& Karagöz, S. (2016). An evaluation of turkish teacher education system compared to other models in different countries. International Journal of Educational Research Review, 1(1), 1-13.

Fajar, A. (2005). Portofolio dalam Pelajaran IPS. PT Remaja Rosdakarya.

Griffith, T. . (2007). The physics of everyday phenomana: A conceptual introduction to physics. McGraw Hill : New York.

Havnes, A., \& McDowell, L. (2007). Balancing dilemmas in assessment and learning in contemporary education. Routledge.

Hubermen, M., \& Miles, M. (2002). The qualitative researcher's companion. Sage.

Janbuala, S., Dhirapongse, S., Issaramanorose, N., \& Iembua, M. (2013). A study of using instructional media to enhance scientific process skill for young children in child development centers in northeastern area. International Forum of Teaching and Studies, 9(2), 41. Retrieved from https://search.proquest.com/openview/8c8fc6938c63eb5b1c9f4c3513cd0db0/1?pqorigsite $=$ gscholar\&cbl $=38579$

Machin, A. (2014). Implementasi pendekatan saintifik, penanaman karakter dan konservasi pada pembelajaran materi pertumbuhan. Jurnal Pendidikan IPA Indonesia, 3(1), 28-35. https://doi.org/10.15294/jpii.v3i1.2898

Majid, A. (2011). Perencanaan pembelajaran (Mengembangkan Standar Kompetensi Guru). PT Remaja Rosdakarya.

Mansvelder-Longayroux, D. D., Beijaard, D., \& Verloop, N. (2007). The portfolio as a tool for stimulating reflection by student teachers. Teaching and Teacher Education, 23(1), 47-62. https://doi.org/10.1016/j.tate.2006.04.033

Marjan, J., Arnyana, I. B. P., \& Setiawan, I. G. a N. (2014). Pengaruh pembelajaran pendekatan saintifik terhadap hasil belajar biologi dan keterampilan proses sains siswa ma $\mathrm{mu}$ ' allimat nw pancor selong kabupaten lombok timur nusa tenggara barat. Jurnal Pendidikan IPA, 4(1), 1-12. Retrieved from http://pasca.undiksha.ac.id/e-journal/index.php/jurnal_ipa/article/view/1316/1017

Mulyono, Y., Bintari, S. H., Rahayu, E. S., \& Widiyaningrum, P. (2012). Pengembangan perangkat pembelajaran dengan pendekatan scientific skill teknologi fermentasi berbasis masalah lingkungan. Lik, 41(1), 20-26.

Olds, B. M., Moskal, B. M., \& Miller, R. L. (2005). Assessment in engineering education: Evolution, approaches and future collaborations. Journal of Engineering Education, 94(1), 13-25. https://doi.org/10.1002/j.2168-9830.2005.tb00826.x

Popham, W. J. (2011). Transformative assessment in action: An inside look at applying the process. ASCD.

Reif, F. (1981). Teaching problem solving--A scientific approach. Physics Teacher, 19(5), 310-316.

Sani, R. A. (2013). Inovasi pembelajaran. Jakarta: Bumi Aksara.

Sanjaya, W. (2008). Kurikulum dan pembelajaran (Teori E Praktek KTSP). Kencana.

ŞİMŞEK, Y. (2017). The evaluation of the application of transported education by teachers. International Journal of Educational Research Review, 2(1), 41-48.

Struyven, K., Dochy, F., Janssens, S., Schelfhou, W., \& Gielen, S. (2006). The overall effects of end-of-course assessment on student performance: A comparison between multiple choice testing, peer assessment, case-based assessment and portfolio assessment. Studies in Educational Evaluation, 32(3), $202-222$. https://doi.org/10.1016/j.stueduc.2006.08.002

Surapranata, S., \& Hatta. (2004). Penilaian portofolio: Implementasi kurikulum 2004. PT Remaja Rosdakarya.

Tiwari, A., \& Tang, C. (2003). From process to outcome: The effect of portfolio assessment on student learning. Nurse Education Today, 23(4), 269-277. https://doi.org/10.1016/S0260-6917(03)00012-1 
Üstünel, E., \& Deren, E. (2010). The effects of e-portfolio based assessment on students' perceptions of educational environment. In Procedia - Social and Behavioral Sciences (Vol. 2, pp. 1477-1481). https://doi.org/10.1016/j.sbspro.2010.03.221

Van den Bergh, V., Mortelmans, D., Spooren, P., Van Petegem, P., Gijbels, D., \& Vanthournout, G. (2006). New Assessment Modes Within Project-Based Education - the Stakeholders. Studies in Educational Evaluation, 32(4), 345-368. https://doi.org/10.1016/j.stueduc.2006.10.005

Van Joolingen, W. R., De Jong, T., Lazonder, A. W., Savelsbergh, E. R., \& Manlove, S. (2005). Co-Lab: Research and development of an online learning environment for collaborative scientific discovery learning. Computers in Human Behavior, 21(4), 671-688. https://doi.org/10.1016/j.chb.2004.10.039

Wieman, C. E. (2007). A scientific approach to scientific writing. Change, 123. https://doi.org/10.3109/17453674.2011.588864 